\begin{tabular}{|c|c|}
\hline Title & Selective synthesis of organogold magic clusters A u54(C $\equiv \mathrm{CPh}) 26$ \\
\hline Author(s) & $\begin{array}{l}\text { Maity, Prasenjit; W akabay ashi, T omonari; Ichikuni, Nobuyuki; T sunoyama, Hironori; X ie, Songhai; Y amauchi, Miho; } \\
\text { T sukuda, T atsuya }\end{array}$ \\
\hline Citation & $\begin{array}{l}\text { Chemical Communications, 48(49), 6085-6087 } \\
\text { https://doi.org/10.1039/c2cc18153c }\end{array}$ \\
\hline Issue Date & 2012-06-21 \\
\hline Doc URL & http:/hdl.handle.net/2115/51999 \\
\hline Rights & Chem. Commun., 2012,48, 6085-6087 - Reproduced by permission of The Royal Society of Chemistry (RSC) \\
\hline Type & article (author version) \\
\hline File Information & CC48-49_6085-6087.pdf \\
\hline
\end{tabular}

Instructions for use 


\title{
Selective synthesis of organogold magic clusters $\mathrm{Au}_{54}(\mathrm{C} \equiv \mathrm{CPh})_{26} \dagger$
}

\author{
Prasenjit Maity, ${ }^{a}$ Tomonari Wakabayashi, ${ }^{b}$ Nobuyuki Ichikuni, ${ }^{c}$ Hironori Tsunoyama, ${ }^{a}$ Songhai Xie, ${ }^{a}$ \\ Miho Yamauchi, ${ }^{a}$ and Tatsuya Tsukuda*a,d
}

Received (in $X X X, X X X)$ Xth $X X X X X X X X X 20 X X$, Accepted Xth $X X X X X X X X X 20 X X$

${ }_{5}$ DOI: 10.1039/b000000x

Organogold clusters $\mathrm{Au}_{54}\left(\mathrm{C}_{2} \mathrm{Ph}\right)_{26}$ were selectively synthesized by reacting of polymer-stabilized Au clusters $(1.2 \pm 0.2 \mathrm{~nm})$ with excess phenylacetylene in chloroform.

Recent studies have shown that gold clusters protected by 10 ligands (phosphines and thiolates) exhibit unique optical, electrochemical, magnetic, and catalytic properties. ${ }^{1-7}$ Such ligand-protected $\mathrm{Au}$ clusters have poteintial applications in diverse fields including catalysis, ${ }^{7-9}$ nanoscale electronics, ${ }^{10-16}$ drug delivery, ${ }^{17}$ molecular biology, ${ }^{18-20}$ and surface 15 patterning. ${ }^{21,22}$ State-of-the-art precision synthesis, theoretical calculations, and single-crystal structure determination have shown that the novel properties of these clusters are associated with cluster substructures, namely the Au core, the ligands, and their interface. Therefore, to design and tune the properties of 20 ligand-protected Au clusters, it is crucial to control the structures of individual substructures; specifically the number of constituent atoms and the geometric structure of the Au core, the interfacial structure between the $\mathrm{Au}$ core and the ligands, and the physicochemical properties of the ligands.

25 In this regard, an interesting challenge is to produce new properties by synergizing the properties of individual substructures. For example, $\mathrm{Au}$ clusters stabilized by $\mathrm{Au}-\mathrm{C}$ covalent bonds (organogold clusters) are anticipated to exhibit novel charge transfer and photophysical properties that differ 30 significantly from those of conventional thiolate-protected $\mathrm{Au}$ clusters. This is because, in organogold clusters, the $\mathrm{Au}$ core and the ligands are coupled more directly via the $\pi-\mathrm{d}$ interaction and the electronic conjugation can be easily extended via $\mathrm{C}=\mathrm{C}$ and/or $\mathrm{C} \equiv \mathrm{C}$ bonds. We recently synthesized the Au clusters stabilized 35 by phenylacetylene $\left(\mathrm{Au}: \mathrm{C}_{2} \mathrm{Ph}\right)$ through $\mathrm{Au}-\mathrm{C}$ covalent bonds. ${ }^{23}$

\footnotetext{
${ }^{a}$ Catalysis Research Center, Hokkaido University, Nishi 10, Kita 21, Sapporo 001-0021, Japan.

${ }^{b}$ Department of Chemistry, School of Science and Engineering, Kinki University, Higashiosaka, 577-8502 Osaka, Japan.

${ }^{c}$ Department of Applied Chemistry and Biotechnology, Graduate School of Engineering, Chiba University, Inage-Ku, Chiba 263-8522, Japan.

d Department of Chemistry, School of Science, The University of Tokyo, 7-3-1 Hongo, Bunkyo-ku, Tokyo 113-0033, Japan. Tel: +81-001-5841-4363; E-mail: tsukuda@chem.s.u-tokyo.ac.jp

$\dagger$ Electronic Supplementary Information (ESI) available: [details of synthesis and characterization]. See DOI: 10.1039/b000000x/
}

Matrix-assisted laser desorption ionization (MALDI) mass spectrometry analysis revealed that as-prepared $\mathrm{Au}: \mathrm{C}_{2} \mathrm{Ph}$ clusters are a mixture of $\mathrm{Au}_{n}\left(\mathrm{C}_{2} \mathrm{Ph}\right)_{m}$ with specific compositions, such as $(n, m)=(43,22),(46,24),(52,26),(54,26),(59,27),(71,32)$, $40(90,36),(94,38),(101,38)$, and $(110,40)$. We herein report selective synthesis and structural characterization of $\mathrm{Au}_{54}\left(\mathrm{C}_{2} \mathrm{Ph}\right)_{26}$.

$\mathrm{Au}: \mathrm{C}_{2} \mathrm{Ph}$ clusters were prepared by mixing the hydrosol of polyvinylpyrrolidone (PVP)-stabilized $\mathrm{Au}$ clusters (Au:PVP) 45 [mean diameter: $1.2 \pm 0.2 \mathrm{~nm}(\mathbf{1 a}), 1.4 \pm 0.2 \mathrm{~nm}(\mathbf{1 b})$, and $1.8 \pm 0.3$ $\mathrm{nm}(\mathbf{1 c})]^{24}$ and an organic solution (toluene or chloroform) of $\mathrm{PhC}_{2} \mathrm{H} .{ }^{23}$ The $\mathrm{PhC}_{2} \mathrm{H}$ to Au molar ratio was $1000 .^{25}$ The reaction temperature was $333 \mathrm{~K}$ and reaction time was $3 \mathrm{~h}$. The $\mathrm{Au}: \mathrm{C}_{2} \mathrm{Ph}$ clusters were purified by repeated washing out very small ${ }_{50} \mathrm{Au}: \mathrm{C}_{2} \mathrm{Ph}$ clusters and excess $\mathrm{PhC}_{2} \mathrm{H}$ with methanol followed by centrifugation. $^{25}$ MALDI mass spectrometry analysis of the thus-produced $\mathrm{Au}: \mathrm{C}_{2} \mathrm{Ph}$ revealed that that the extraction solvent employed and the Au:PVP size distribution greatly affect selective synthesis of $\mathrm{Au}_{54}\left(\mathrm{C}_{2} \mathrm{Ph}\right)_{26}$.

55 We first show the effect of the extraction solvent on the size distribution of $\mathrm{Au}: \mathrm{C}_{2} \mathrm{Ph}$. Figures $1 \mathrm{a}$ and $1 \mathrm{~b}$ compare the appearances of ligand exchange in toluene and chloroform, respectively. Initially (i.e., at $0 \mathrm{~h}$ ), the aqueous phases containing
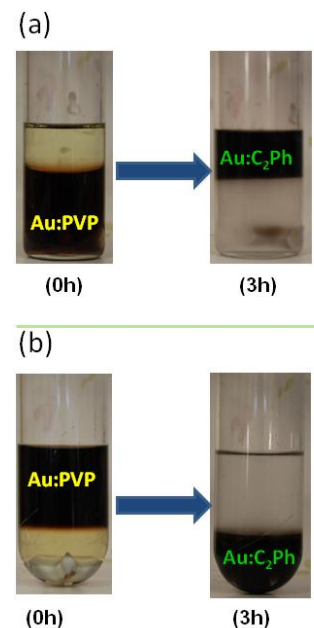

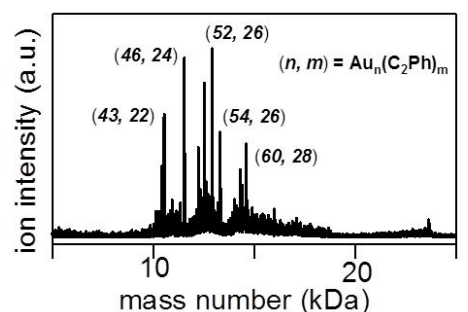

mass number $(\mathrm{kDa})$

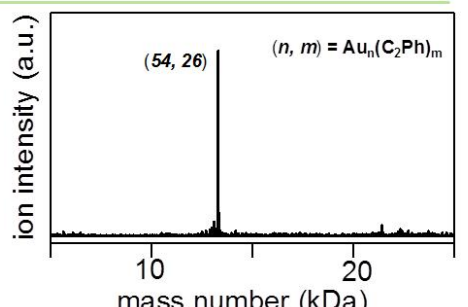

Figure 1. Photographs of the phase transfer reaction for $\mathrm{Au}: \mathrm{C}_{2} \mathrm{Ph}$ synthesis and negative-ion MALDI mass spectra of $\mathrm{Au}: \mathrm{C}_{2} \mathrm{Ph}$ prepared using (a) toluene and (b) chloroform. 
$\mathrm{Au}: \mathrm{PVP}$ were brown and the organic phases containing $\mathrm{PhC}_{2} \mathrm{H}$ were colourless. After $3 \mathrm{~h}$, the water phases became colourless and the organic phases turned deep brown, indicating completion of ligand exchange. The $\mathrm{Au}: \mathrm{C}_{2} \mathrm{Ph}$ yield was higher when using 5 chloroform $(\sim 90 \%)$ than when using toluene $(\sim 60 \%)$. The $\mathrm{Au}: \mathrm{C}_{2} \mathrm{Ph}$ size distributions obtained using toluene and chloroform differed remarkably. MALDI mass spectrometry analysis indicated that $\mathrm{Au}_{54}\left(\mathrm{C}_{2} \mathrm{Ph}\right)_{26}$ was selectively formed when using chloroform (Figure 1b), whereas $\mathrm{Au}: \mathrm{C}_{2} \mathrm{Ph}$ prepared using toluene 10 contained clusters with different compositions (Figure 1a).

We next show the effect of the initial size of $\mathrm{Au}$ clusters in $\mathrm{PVP}$ on the size distribution of $\mathrm{Au}: \mathrm{C}_{2} \mathrm{Ph}$. Figure 2 shows MALDI mass spectra of $\mathrm{Au}: \mathrm{C}_{2} \mathrm{Ph}$ obtained from Au:PVP (1a-1c) under chloroform-water biphasic condition. The smallest Au:PVP (1a) 15 gave the highest selectivity to $\mathrm{Au}_{54}\left(\mathrm{C}_{2} \mathrm{Ph}\right)_{26}$, whereas the selectivity was lower for larger Au:PVP (1b and 1c). Under optimized conditions, we could produce $\sim 5 \mathrm{mg}$ of $\mathrm{Au}_{54}\left(\mathrm{C}_{2} \mathrm{Ph}\right)_{26}$ from $1 \mathbf{a}$ in a single synthesis. ${ }^{25}$

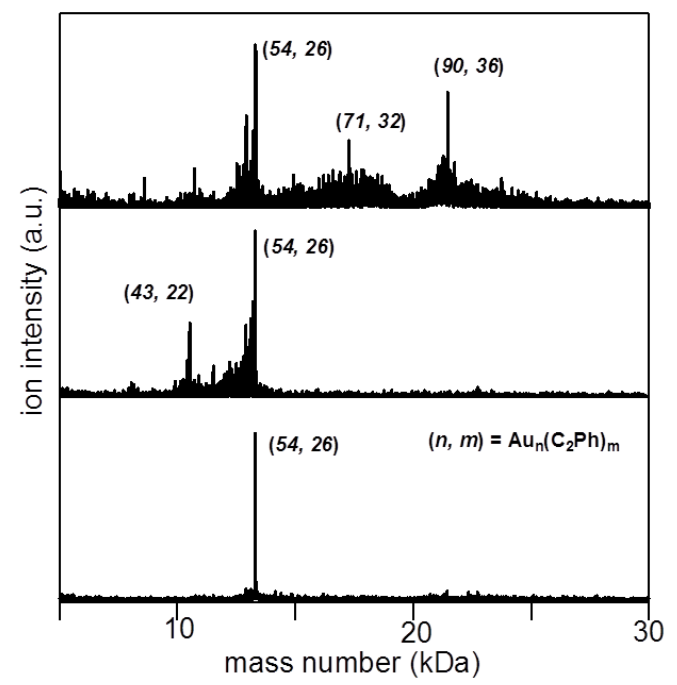

Figure 2. Negative ion MALDI mass spectra of $\mathrm{Au}: \mathrm{C}_{2} \mathrm{Ph}$ produced from 1a (below), 1b (middle), and 1c (above) using chloroform as the extraction solvent.

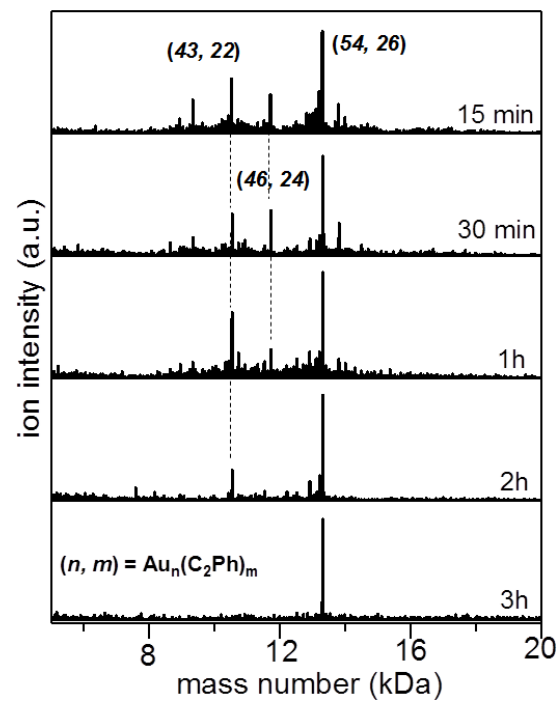

Figure 3. Negative-ion MALDI mass spectra of $\mathrm{Au}: \mathrm{C}_{2} \mathrm{Ph}$ obtained from Au:PVP (1a) for five different reaction times.
The selective formation of $\mathrm{Au}_{54}\left(\mathrm{C}_{2} \mathrm{Ph}\right)_{26}$ in chloroform from $20 \mathrm{Au}: \mathrm{PVP}$ (1a) can be explained in terms of thermodynamic stability of $\mathrm{Au}_{54}\left(\mathrm{C}_{2} \mathrm{Ph}\right)_{26}$ as well as kinetic factors. Figure 3 shows MALDI mass spectra of the products obtained from 1a at different stages of the reaction in chloroform. Initially formed $\mathrm{Au}_{43}\left(\mathrm{C}_{2} \mathrm{Ph}\right)_{22}, \mathrm{Au}_{46}\left(\mathrm{C}_{2} \mathrm{Ph}\right)_{24}$ and some others disappeared and 25 only $\mathrm{Au}_{54}\left(\mathrm{C}_{2} \mathrm{Ph}\right)_{26}$ remained after $3 \mathrm{~h}$. This observation clearly indicates that complete selectivity to $\mathrm{Au}_{54}\left(\mathrm{C}_{2} \mathrm{Ph}\right)_{26}$ was achieved by disappearance of all the other metastable species which are concomitantly populated just after the completion of the ligation to the Au clusters. Chemical etching of the Au core was proposed 30 as a decomposition route of metastable $\mathrm{Au}$ clusters in the selective formation of $\mathrm{Au}_{25}(\mathrm{SG})_{18}$ via the ligand exchange of glutathione (GSH) and GS-protected Au clusters. ${ }^{26}$ More efficient conversion in chloroform than in toluene (Figure 1) is ascribed to more efficient core etching of $\mathrm{Au}: \mathrm{C}_{2} \mathrm{Ph}$ in chloroform due to their 35 higher solubility. Whatever the mechanism of the selective decomposition might be, a proper size distribution of the nascent $\mathrm{Au}: \mathrm{C}_{2} \mathrm{Ph}$ clusters is a key for the selective and high-yield synthesis of thermodynamically and chemically stable $\mathrm{Au}_{54}\left(\mathrm{C}_{2} \mathrm{Ph}\right)_{26}$.

40 To obtain information about the $\mathrm{Au}$ core structure of $\mathrm{Au}_{54}\left(\mathrm{C}_{2} \mathrm{Ph}\right)_{26}, \mathrm{Au}: \mathrm{C}_{2} \mathrm{Ph}$ produced from 1a using chloroform was characterized by transmission electron microscopy (TEM), UV-visible spectroscopy, X-ray photoelectron spectroscopy (XPS), powder X-ray diffraction (XRD), X-ray absorption 45 near-edge structure (XANES) spectroscopy, and extended X-ray absorption fine structure (EXAFS) spectroscopy. The TEM image (Figure 4a) clearly shows that the clusters are monodisperse (mean diameter: $1.3 \pm 0.2 \mathrm{~nm}$ ) and do not contain impurities of larger nanoparticles. The UV-visible spectrum 50 (Figure 4b) exhibits an exponential-like profile without the surface plasmon peak. The Au 4f XP spectrum (Figure 4c) shows that $\mathrm{Au} 4 \mathrm{f}_{7 / 2}$ has a binding energy of $84.3 \mathrm{eV}$, which is slightly higher than that of bulk gold $(84.0 \mathrm{eV})$. This suggests that electron transfer occurs from the $\mathrm{Au}$ cores to the $\mathrm{PhC}_{2}$ ligands.

${ }_{55}$ The XRD pattern shows diffraction peaks from the Au lattice
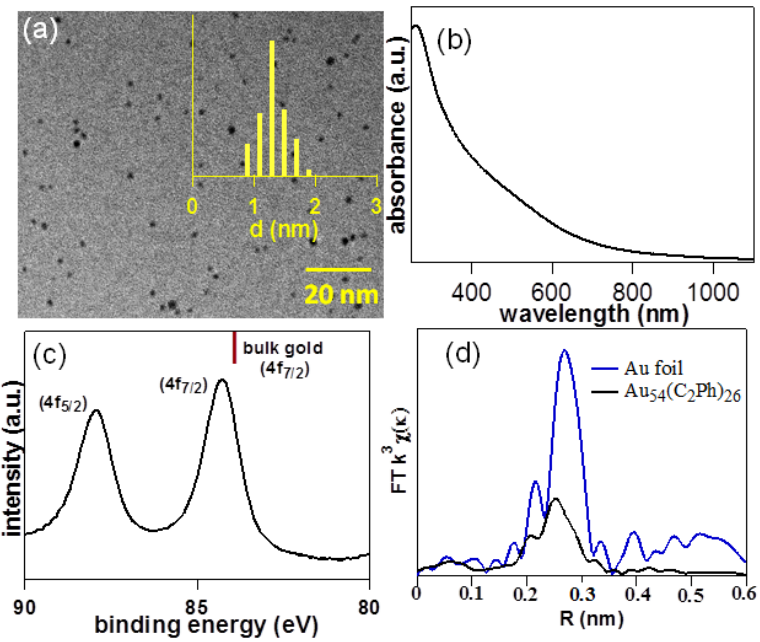

Figure 4. (a) TEM image and size distribution; (b) UV-visible spectrum in chloroform; (c) XP spectrum in the vicinity of Au 4f, (d) Fourier-transform EXAFS spectrum of $\mathrm{Au}_{54}\left(\mathrm{C}_{2} \mathrm{Ph}\right)_{26}$. 
planes with a smaller lattice constant. ${ }^{25}$ The XANES spectrum indicates that absorption onset for $\mathrm{Au}_{54}\left(\mathrm{C}_{2} \mathrm{Ph}\right)_{26}(11920.38 \mathrm{eV})$ was the same as that of an $\mathrm{Au}$ foil $(11920.38 \mathrm{eV}) .{ }^{25}$ Figure $4 \mathrm{~d}$ shows a $k^{3}$-weighted Fourier-transform EXAFS spectrum of ${ }_{5} \mathrm{Au}_{54}\left(\mathrm{C}_{2} \mathrm{Ph}\right)_{26}$. The peak in the range of $0.221-0.313 \mathrm{~nm}$ is assigned to the $\mathrm{Au}-\mathrm{Au}$ shell. From a curve-fitting analysis, ${ }^{25}$ the $\mathrm{Au}-\mathrm{Au}$ distance was determined to be $0.279 \mathrm{~nm}$, which is significantly smaller than that in the bulk $(0.289 \mathrm{~nm})$. The $\mathrm{Au}-\mathrm{Au}$ coordination number $(\mathrm{CN})$ for $\mathrm{Au}_{54}\left(\mathrm{C}_{2} \mathrm{Ph}\right)_{26}$ was 10 calculated to be $7.3 \pm 1.6$ by assuming that the electron mean free path is $0.5 \mathrm{~nm}^{27}$ This $\mathrm{CN}$ value is comparable to that (7.9) of cuboctahedral $\mathrm{Au}_{55}$. These results clearly show the formation of small Au cores in $\mathrm{Au}_{54}\left(\mathrm{C}_{2} \mathrm{Ph}\right)_{26}$.

Recently, Chen and co-workers reported formation of two 15 types of bonding of carbon of the ligands to $\mathrm{Ru}$ nanoparticles; $\mathrm{Ru}$-alkynide $(\mathrm{Ru}-\mathrm{C} \equiv \mathrm{C}-)^{28}$ and $\mathrm{Ru}$-vinylidene $(\mathrm{Ru}=\mathrm{C}=\mathrm{CH}-)^{29}$ Our mass analysis supported the formation of $\mathrm{Au}_{54}(-\mathrm{C} \equiv \mathrm{C}-\mathrm{Ph})_{26}$ rather than $\mathrm{Au}_{54}(=\mathrm{C}=\mathrm{CH}-\mathrm{Ph})_{26}{ }^{25}$ To obtain further insight into the interfacial structure of $\mathrm{Au}_{54}\left(\mathrm{C}_{2} \mathrm{Ph}\right)_{26}$, we measured the 20 Fourier-transform infrared (FTIR) and Raman spectra (Figure 5). Absence of $\mathrm{C}-\mathrm{H}$ vibrational peak in the FTIR spectrum ${ }^{25}$ indicates the direct bonding between carbon and gold in $\mathrm{Au}_{54}\left(\mathrm{C}_{2} \mathrm{Ph}\right)_{26}$. Figure 5 shows that the peak for the $-\mathrm{C} \equiv \mathrm{C}-$ stretching mode of $\mathrm{PhC}_{2} \mathrm{H}\left(2110 \mathrm{~cm}^{-1}\right)^{30}$ is red shifted to 2028 ${ }_{25} \mathrm{~cm}^{-1}$ for the ligands of $\mathrm{Au}_{54}\left(\mathrm{C}_{2} \mathrm{Ph}\right)_{26}$. This suggests that alkynyl carbon binds covalently with gold and that the $-\mathrm{C} \equiv \mathrm{C}-$ bond is weakened by electron transfer from the Au core to the $\pi^{*}$ orbital of the $\mathrm{PhC}_{2}$ ligands.

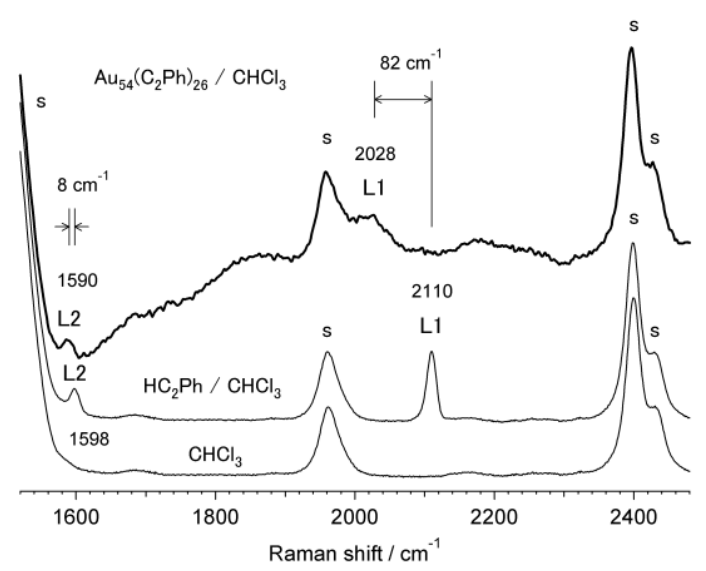

Figure 5. Raman spectra of $\mathrm{Au}_{54}\left(\mathrm{C}_{2} \mathrm{Ph}\right)_{26}$ (top) and $\mathrm{PhC}_{2} \mathrm{H}$ (middle) in chloroform with $532 \mathrm{~nm}$ excitation. The spectrum of chloroform is shown for comparison (bottom). Peaks indicated by L1 and L2 correspond to the stretching mode of $\mathrm{C} \equiv \mathrm{C}$ and in-plain stretching mode of the phenyl group of $\mathrm{PhC}_{2} \mathrm{H}$ (L2), respectively. The peaks due to the solvent are indicated by "s".

In summary, we have developed a selective and high yield 30 synthetic method of $\mathrm{Au}_{54}\left(\mathrm{C}_{2} \mathrm{Ph}\right)_{26}$ by controlling the initial cluster sizes of Au:PVP and the solvents for the ligand exchange. Large-scale synthesis of a new magic cluster $\mathrm{Au}_{54}\left(\mathrm{C}_{2} \mathrm{Ph}\right)_{26}$ will open up the possibility of gaining a deeper understanding of the structure and properties as well as realizing practical applications. 35

This research was financially supported by the Funding Program for Next Generation World-Leading Researchers (NEXT Program) (GR-003).

\section{Notes and references}

40 1. R. L. Whetten, J. T. Khoury, M. M. Alvarez, S. Murthy, I. Vezmar, Z. L. Wang, P. W. Stephens, C. L. Cleveland, W. D. Luedtke and U, Landman, Adv. Mater., 1996, 8, 428.

2. A. C. Templeton, W. P. Wuelfing and R. W. Murray, Acc. Chem. Res., 2000, 33, 27.

453 T. Laaksonen, V. Ruiz, P. Liljerothc and B. M. Quinn, Chem. Soc. Rev. 2008, 37, 1836.

4 T. Tsukuda, Bull. Chem. Soc. Jpn., (DOI:10.1246/bcsj.20110227)

5 Y. Negishi, H. Tsunoyama, M. Suzuki, N. Kawamura, M. M. Matsushita, K. Maruyama, T. Sugawara, T. Yokoyama and T. Tsukuda, $J$. 50 Am. Chem. Soc., 2006, 128, 12034.

6 M-C. Daniel and D. Astruc, Chem. Rev., 2004, 104, 293.

7 Y. Zhu, H. Qian, M. Zhu and R. Jin, Adv. Mater., 2010, 22, 1915.

8 Y. Zhu, Z. Wu, C. Gayathri, H. Qian, R. R. Gil and R. Jin, J. Catal., 2010, 271, 155.

559 Y. Zhu, H. Qian, B. A. Drake and R. Jin, Angew. Chem. Int. Ed., 2010, 49, 1295.

10 V. Ruiz, A. Colina, A. Heras and J. Lopez-Palacios, Small, 2006, 2, 56.

11 M. Burghard, G. Philipp, S. Roth, K. von Klitzing, R. Pugin and G. 60 Schmid, Adv. Mater., 1998, 10, 842.

12 H. Imahori and S. Fukuzumi, Adv. Mater., 2001, 13, 1197.

13 P. Schwerdtfeger, Angew. Chem. Int. Ed. 2003, 42, 1892.

14 N. Sakai and T. Tatsuma, Adv. Mater., 2010, 22, 3185.

15 P. Liljeroth, B. M. Quinn, V. Ruiz and K. Kontturi, Chem. Commun., $652003,1570$.

16 K. G. Thomas and P. V. Kamat, Acc. Chem. Res., 2003, 36, 888.

17 P. Ghosh, G. Han, M. De, C. K. Kim and V. M. Rotello, Adv. Drug. Deliv. Rev. 2008, 60, 1307

18 R. Zhou, M. Shi, X. Chen, M. Wang and H. Chen, Chem. Eur. J. $702009, \mathbf{1 5}, 4944$.

19 M. A. H. Muhammed, P. K. Verma, S. K. Pal, A. Retnakumari, M. Koyakutty, S. Nair, and T. Pradeep, Chem. Eur. J. 2010, 16, 10103.

20 R. A. Sperling, P. Rivera Gil, F. Zhang, M. Zanella and W. J. Parak, Chem. Soc. Rev., 2008, 37, 1896.

7521 W. P. Wuelfing, S. J. Green, J. J. Pietron, D. E. Cliffel, and R. W. Murray, J. Am. Chem. Soc. 2000, 122, 11465

22. M. Aslam, I. S. Mulla, and K. Vijayamohanan, Langmuir, 2001, 17, 7487.

23. P. Maity, H. Tsunoyama, M. Yamauchi, S. Xie and T. Tsukuda, J. Am. 80 Chem. Soc., 2011, 133, 20123.

24 (a) H. Tsunoyama, H. Sakurai, Y. Negishi and T. Tsukuda, J. Am. Chem. Soc., 2005, 127, 9374; (b) H. Tsunoyama, N. Ichikuni and T. Tsukuda, Langmuir, 2008, 24, 11327; (c) H. Tsunoyama and T. Tsukuda, J. Am. Chem. Soc., 2009, 131, 18216.

8525 See Supporting Information.

26. Y. Shichibu, Y. Negishi, H. Tsunoyama, M. Kanehara, T. Teranishi, and T. Tsukuda, Small, 2007, 3, 835.

27. J. Zhao and P. A. Montano, Phys. Rev. B 1989, 40, 3401.

28. W. Chen, N. B. Zuckerman, X. W. Kang, D. Ghosh, J. P. 90 Konopelski, S. W. Chen, J. Phys. Chem. C 2010, 114, 18146.

29. X. Kang, N. B. Zuckerman, J. P. Konopelski and S. Chen, J. Am. Chem. Soc., 2012, 134, 1412.

30. (a) T. Wakabayashi, T. Murakami, H. Nagayama, D. Nishide, H. Kataura, Y. Achiba, H. Tabata, S. Hayashi and H. Shinohara, Eur. Phys. J. 95 D, 2009, 52, 79; (b) W. Chen, N. B. Zuckerman, X. Kang, D. Ghosh, J. P. Konopelski, and S. Chen, J. Phys. Chem., C 2010, 114, 18146; (c) S. Back, R. A. Gossage, G. Rheinwald, I. del Rio, H. Lang and G. Van Koten, J. Organomet. Chem., 1999, 582, 126.

100 


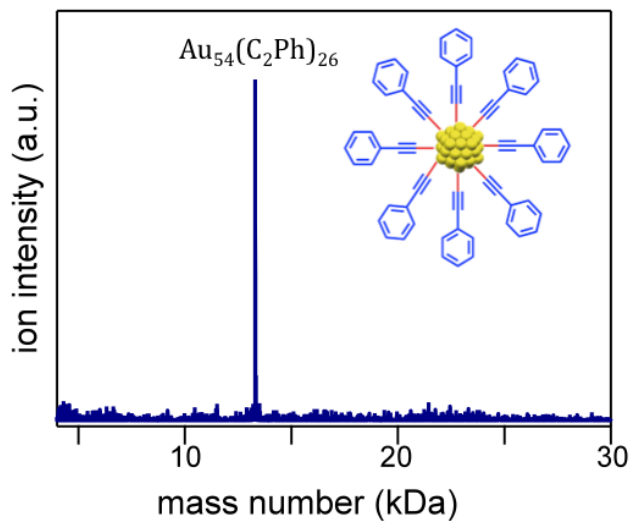

Organogold clusters $\mathrm{Au}_{54}\left(\mathrm{C}_{2} \mathrm{Ph}\right)_{26}$ were selectively synthesized by reacting polymer-stabilized Au clusters $(1.2 \pm 0.2 \mathrm{~nm})$ with excess phenylacetylene in chloroform. 